\title{
Microhabitat use by species of the genera Bothrops and Crotalus (Viperidae) in semi-extensive captivity
}

Gomes CA (1, 2), Almeida-Santos SM (1, 2)

(1) Laboratory of Ecology and Evolution, Butantan Institute, São Paulo, São Paulo State, Brazil; (2) Graduate Program in Animal Biology, Institute of Biosciences, Language Studies and Exact Sciences, São Paulo State University (UNESP - Univ Estadual Paulista), São José do Rio Preto, São Paulo State, Brazil.

\begin{abstract}
Many factors influence microhabitat including climate and the occurrence of predators, prey and suitable shelters. The influence of predators in a semi-extensive breeding system is minimized due to frequent monitoring of the area. This situation enables the independent analysis of such other variables as refuges and temperature. Some specimens of the Viperidae family are kept in a semi-extensive breeding system at the Butantan Institute for display and study. These animals are widely distributed in the Atlantic Forest and Cerrado, two biomes with distinct climatic characteristics. We compared the daily activity pattern and microhabitat use of the species Bothrops jararaca and Crotalus durissus terrificus. Our main questions were whether rattlesnakes and lancehead snakes respond to habitat selection differently in similar climatic conditions and if they choose similar microhabitats. Species of the genus Bothrops were frequently found under shelters regardless of the time of day. On the other hand, snakes of the genus Crotalus were frequently found sheltered during the early morning, then migrated to sunnier areas and returned to shelters in late afternoon.
\end{abstract}

Key words: microhabitat selection, snakes, thermoregulation, Viperidae.

\section{INTRODUCTION}

Studies on snake habitat selection are increasing due to the use of radio-tracking and mark-recapture techniques (1-5). Although these techniques are more commonly used in the field, other methods are employed in semi-extensive breeding for individual identification (6). Semiextensive breeding can provide new information on snakes' habits such as segregation, habitat use, and thermoregulation $(2,6,7)$.

Three snake genera of the Viperidae family occur in Brazil: Lachesis, Bothrops and Crotalus. Snakes of the genus Bothrops are widely distributed in the Atlantic Forest, though it is known that they can inhabit areas disturbed by human activity (812). On the other hand, Brazilian rattlesnakes generally live in dry open areas known as Cerrado but can also be associated with transition areas $(13,14)$.

In this study we analyzed microhabitat selection by snakes under semi-extensive breeding, in order to provide information about preferred substrate and thermoregulation sites. Since this environment presents controlled feeding, availability of different shelters and a low occurrence of predators, we hypothesize that the preference for a specific site should be influenced solely by thermoregulation.

\section{MATERIALS AND METHODS}

The experiment was conducted at the Butantan Institute, São Paulo ( $23^{\circ} 34^{\prime}$ S; $46^{\circ} 42^{\prime} \mathrm{W}$ ). The 
serpentarium is a semi-extensive breeding site destined for research and public visitation. It consists of a pit $3 \mathrm{~m}$ high, $13 \mathrm{~m}$ wide, and 50 $\mathrm{m}$ long, divided into three areas, each of which harbors a different genus of snakes: Bothrops, Boa, or Crotalus (Figure 1). The soil is covered by grass

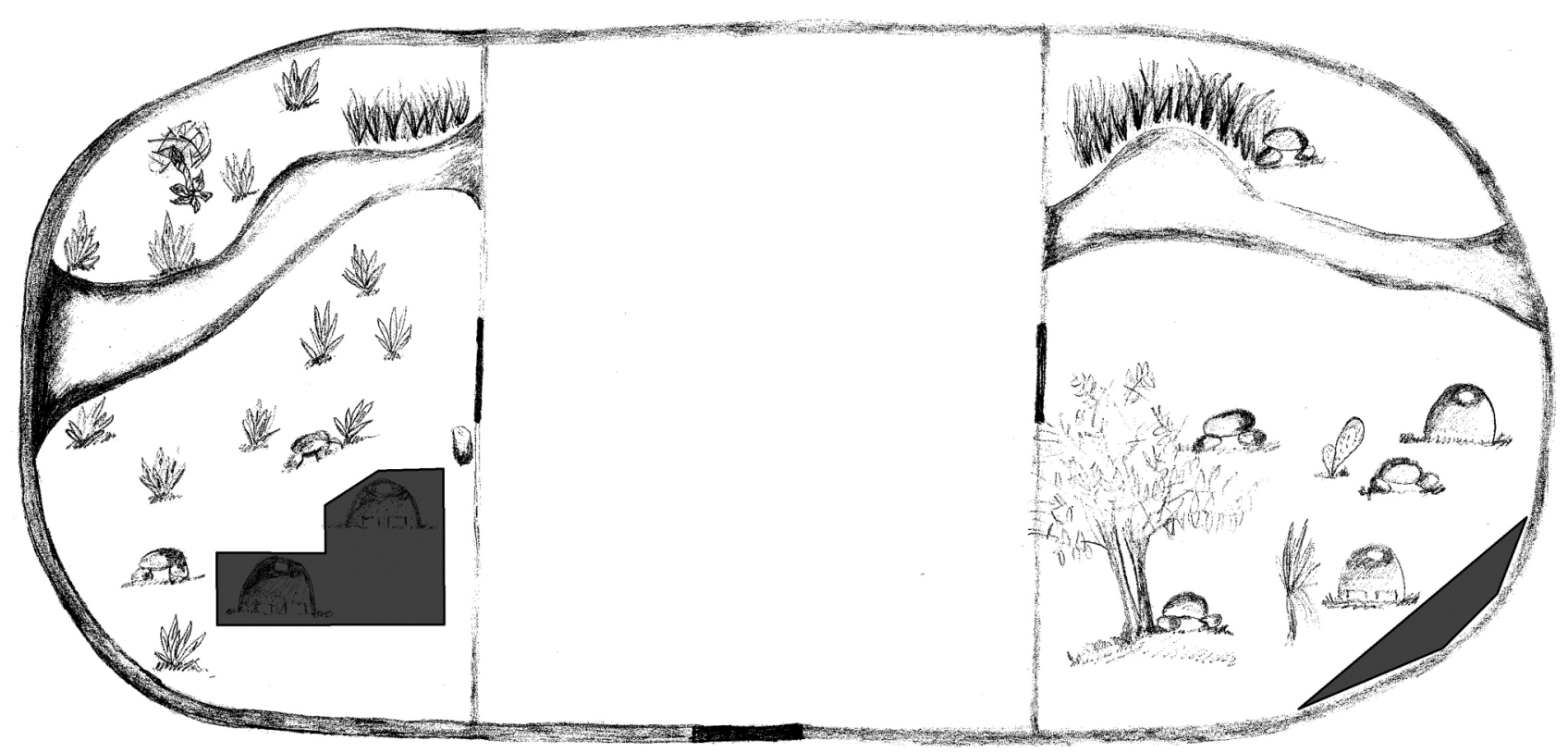

Figure 1. Aerial view of serpentarium: Bothrops species are on the left and Crotalus to the right. Areas in black indicate more frequent snake occurrence.

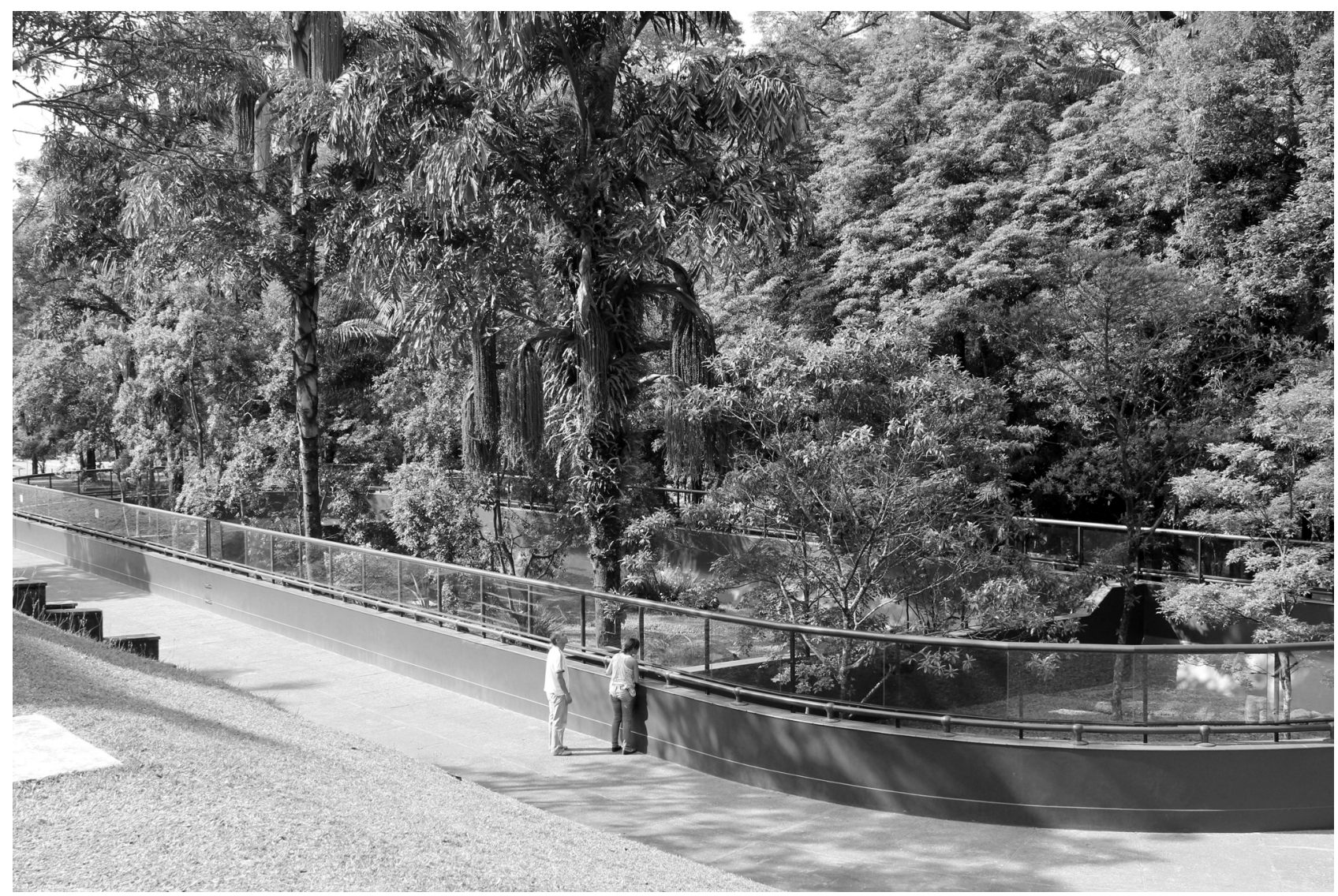

Figure 2. External view of serpentarium. 
and small stones. Moreover, the ornamentations of this enclosure can be used as shelters. There are four ornamentation types: shrubs, trees, igloos, and rocks (Figure 2).

From sunrise until noon, sunlight is directed toward the Bothrops enclosure. In the afternoon until dusk, sunlight incidence is concentrated on the Crotalus area, warming mainly the right wall.

During the study, the maximum number of snakes was 45 (32 Crotalus durissus terrificus and 13 Bothrops jararaca). All specimens have a microchip under their skin. To facilitate identification, the tail of each animal was painted with nail polish of a different color (6).

Data sampling was made in two periods, from June to November of 2008 and March to April of 2009. To avoid a time-of-day influence on observations, we alternated data sampling between the morning and afternoon on each day. We recorded the places used as shelters, the individuals found in them, and the temperature (Ts) using a Hygro-Thermometer Clock ${ }^{\circ}$ (Instrutherm, Brazil). This process was also used for unsheltered snakes (Tu). Data on daily temperature ( $\mathrm{Ta}$ ) was provided by a weather station controlled by the University of São Paulo (USP). The time of observations may also influence habitat selection. Thus, we analyzed morning and afternoon data separately. We tested the normality of data prior to the analysis using the Shapiro-Wilk test. ANOVA or KruskalWallis test was used to verify mean temperature variation. Statistical analysis was performed via the software Statistica 8 (StatSoft, USA).

\section{RESULTS}

As expected, temperature differed between the wet season (spring and summer) and dry season (fall and winter) $(t=-6.28, p<0.001)$. However, each species showed the same pattern of microhabitat selection in both seasons (Figure $3 \mathrm{~A}$ and B). Microhabitat selection was based on substrate temperature in both the morning and afternoon. During early morning, shelter temperature (Ts) and unsheltered temperature $(\mathrm{Tu})$ were higher than ambient temperature $(\mathrm{Ta})$ $(\mathrm{K}=38.90 ; p<0.001)$. The same pattern was observed in the afternoon $(\mathrm{K}=57.56 ; p<0.001)$ (Figure 4).

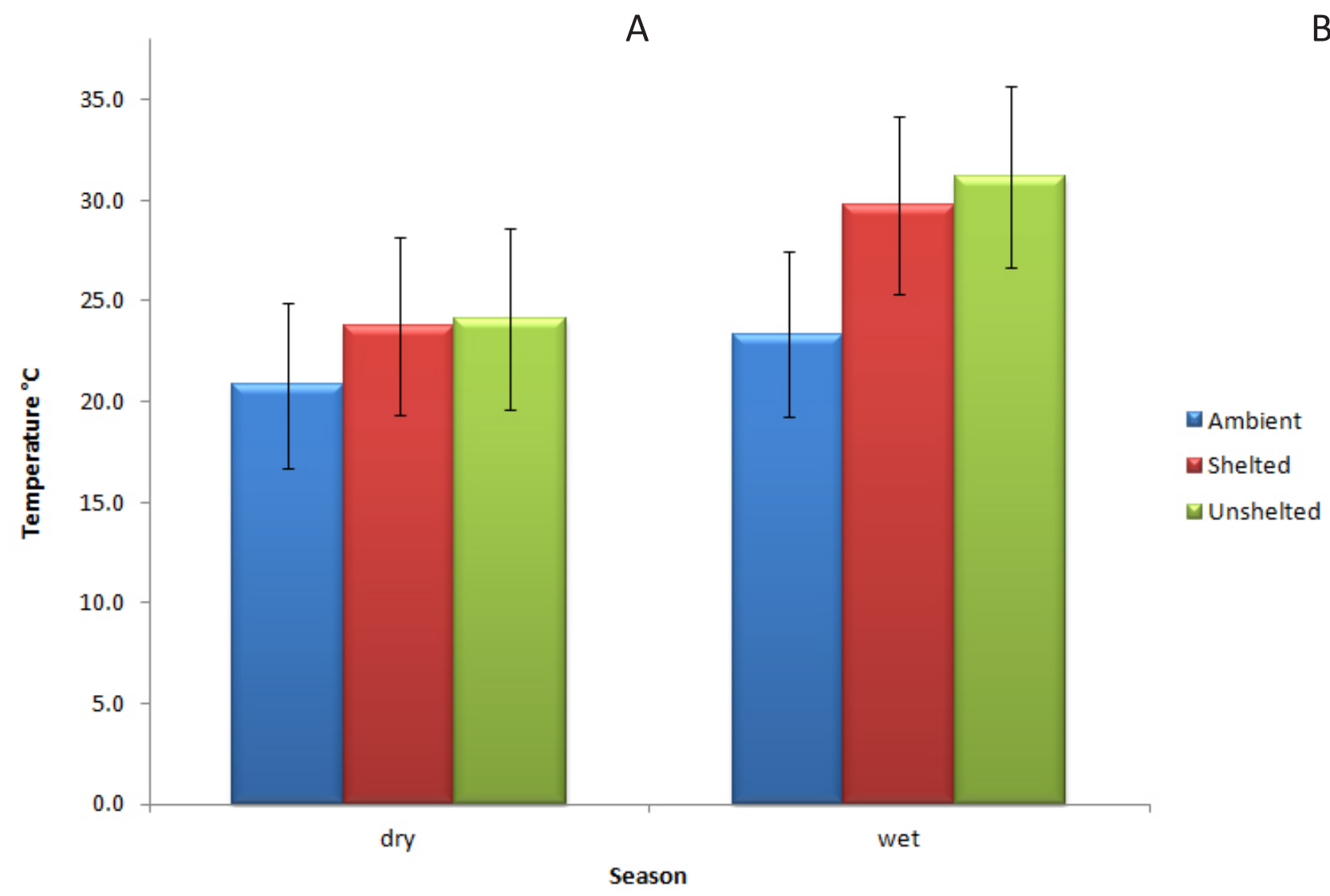

Figure 3. Temperature variation $\left({ }^{\circ} \mathrm{C}\right)$ by season for the genus Crotalus. 


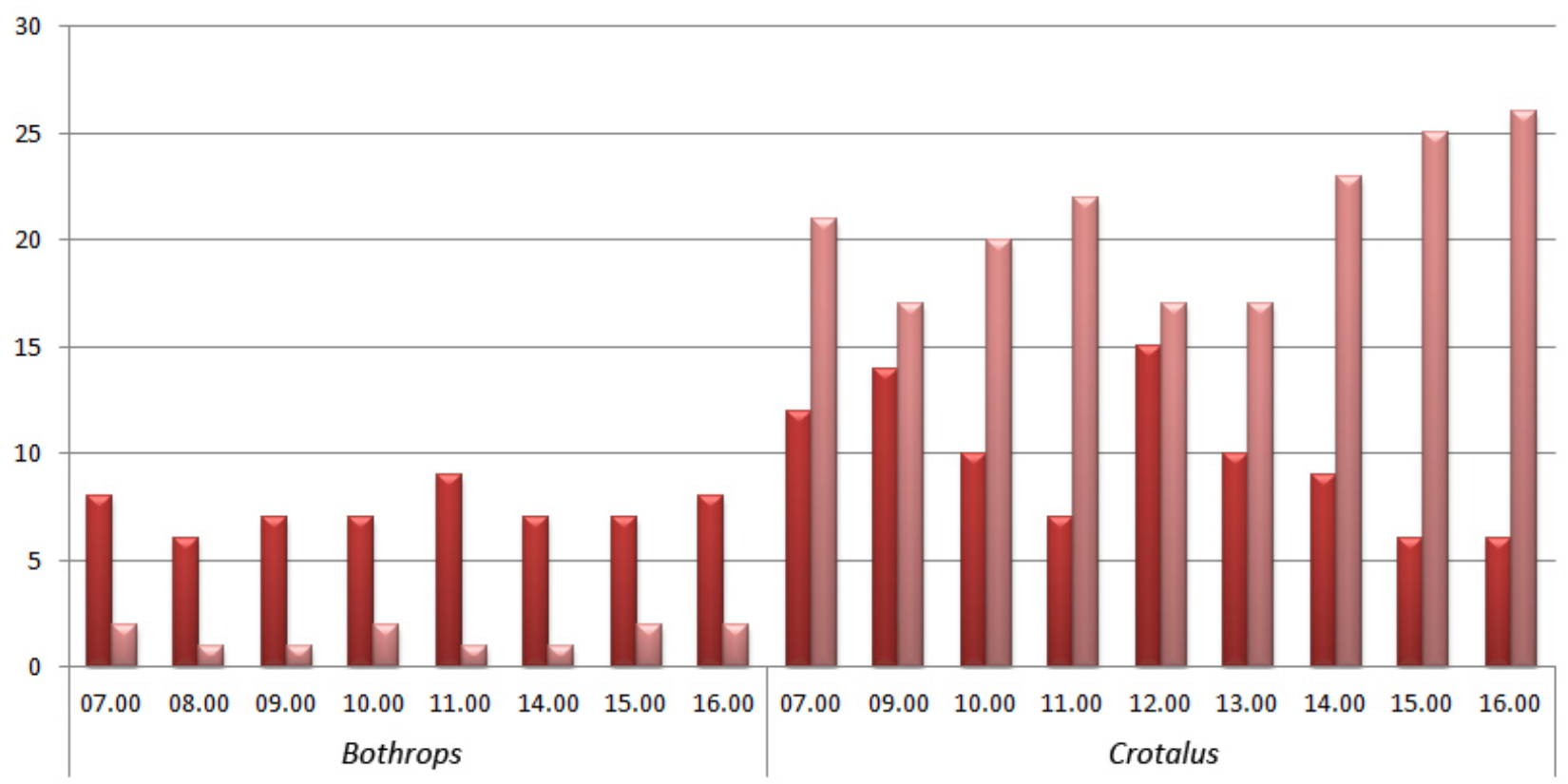

Figure 4. Daily microhabitat distribution of Bothrops and Crotalus.

Snakes of the specie Bothrops jararaca were found in shelters $82 \%$ of the time. No significant difference between $\mathrm{Ts}$ and $\mathrm{Tu}$ was found $(\mathrm{K}=1.59$; $p=0.8$ ). Thus, temperature data were pooled and treated as Ts. mean Ts was higher in afternoon $(\mathrm{K}$ $=49.46 ; p<0.001)$ and higher than $\mathrm{Ta}$ on both periods $(\mathrm{Ts}=20.1 \pm 3.9 ; \mathrm{Ta}=19.1 \pm 3.5 ; \mathrm{t}=3.71$; $p<0.001$ for morning; and $\mathrm{Ts}=24.3 \pm 5.1 ; \mathrm{Ta}$ $=21.5 \pm 4.3 ; t=10.52 ; p<0.001$ for afternoon). Microhabitat selection did not differ significantly between the morning and afternoon $(\mathrm{F}=1.81$; $p$ $=0.18$; Figure 4).

The species Crotalus durissus terrificus was found in shelters $40 \%$ of the time. The Ts of Crotalus was higher in the afternoon than in the morning ( $\mathrm{K}=50.05 ; p<0.001)$. Microhabitat selection was more evident in the morning when compared to the afternoon (means $11 \pm 4 ; 6 \pm 5$ individuals, respectively; $\mathrm{K}=11.94 ; p<0.001$ ). From 7:45 until 9:45 a.m., snakes used shelters more frequently than during other periods. In the afternoon, most were basking in the sun (Figures 4 and 5). This selection was made both in the wet and dry seasons (Figure $3 \mathrm{~A}$ and $\mathrm{B}$ ).

We analyzed the three variables (microhabitat, time of day, and genus). Bothrops and Crotalus chose different types of microhabitat (shelter vs. unsheltered), regardless of the period of the day $(\mathrm{F}=677.20 ; p<0.001)$. Snake genus may explain microhabitat choice more than time of day $(\mathrm{F}=$ 17.23; $p<0.001$; Figure 4).

\section{DISCUSSION}

Similarly to other ectotherms, snakes of the species Bothrops jararaca and Crotalus durissus terrificus take refuge in warmer shelters during the night (1-2,7-6). However, the patterns we observed differed between species of the two genera. Bothrops remained in shelters and was rarely uncovered. On the other hand, rattlesnakes (and other snakes) display a more active basking behavior, standing directly in sunlight or in cooler refuges $(15,16)$. Similar results for Crotalus were found by Tozetti and Martins (3), although they indicate an absence of habitat selection during the day.

We believe that the results for $B$. jararaca may be influenced by its original geographic distribution, dense rain forests with a wide variety of shelters (11). This specie is largely nocturnal and uses sun-shade mosaic for basking (11). We believe that microhabitat selection occurs to maintain the physiological temperature, using shelters, which are warmer (Ts) than the ambient temperature $(\mathrm{Ta})$. This pattern persisted even in warmer afternoons, allowing snakes to bask under cover (11). 


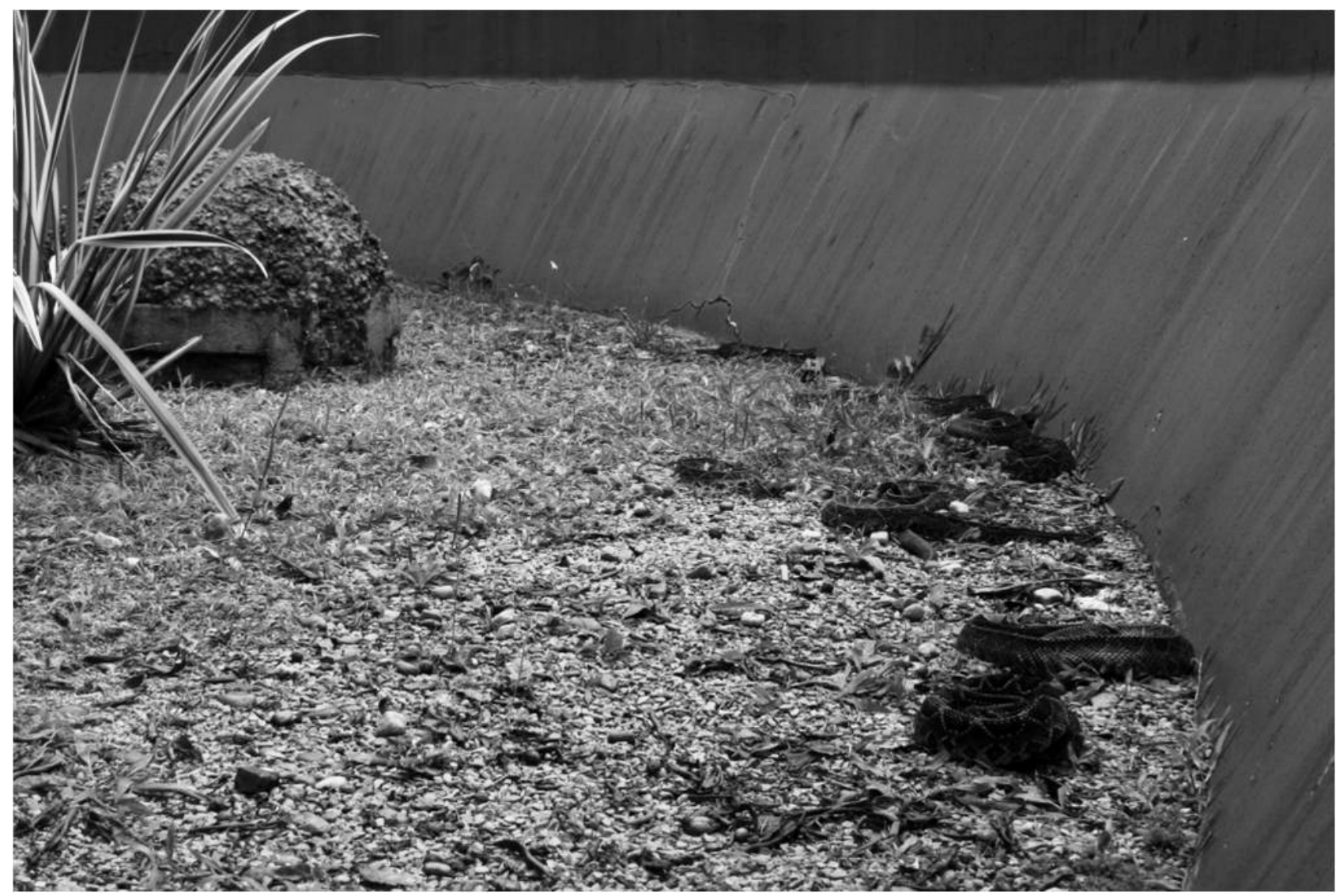

Figure 5. Crotalus basking in the sun during the afternoon.

Crotalus durissus is a nocturnal snake that displays peak activity from 6 to 9 p.m. (17). This species commonly inhabits the Brazilian Cerrado and Caatinga, both hot dry environments, formed mostly by desert vegetation and rocks $(12,13)$. This biome provides some refuges used to maintain a warmer temperature at night. Daily activity is concentrated in the warmest part of the day, confirming that rattlesnakes spend most of the day resting (Figure 5).

We showed that data recorded in a restricted environment, such as semi-intensive breeding, can corroborate the data from the field (3). Furthermore, we found that both species $C$. durissus and $B$. jararaca have similar patterns of annual activity $(18,19)$. There are two activity peaks, one at the transition from summer to fall, related to mating season, in which both males and females are active. The second peak occurs in the spring, when females are pregnant or giving birth.

Even under the same climatic conditions, species of the genera Bothrops and Crotalus showed different activity patterns. This behavior maybe innate, since outside the natural conditions snakes maintain their natural behavior. Another hypothesis is that the physiological temperature maintenance requires the snakes to select different microhabitats as well as distinct activity patterns.

Given the continuing decline of many populations of wild animals, studies of animals under restricted environments, such as semiextensive captivity breeding, generate basic research that could be used as models for future works and in situ conservation.

The activity pattern of Bothrops jararaca answers visitors' main query: "Why are these snakes not easily found wandering in the serpentarium as rattlesnakes do?".

\section{ACKNOWLEDGMENTS}

We thank the Laboratory of Ecology and Evolution staff team for data sampling and snakes maintenance on serpentarium, Verônica A. Barros for English review and Ana B. Barros for the serpentarium drawing. 


\section{COPYRIGHT}

\section{(C) CEVAP 2012}

\section{SUBMISSION STATUS}

Received: June 14, 2012.

Accepted: September 11, 2012.

Abstract published online: September 14, 2012.

Full paper published online: November 30, 2012.

\section{CONFLICTS OF INTEREST}

The authors declare no conflicts of interest.

\section{FINANCIAL SOURCE}

The São Paulo State Health Secretariat and the National Council for Scientific and Technological Development $(\mathrm{CNPq})$ provided the financial grants.

\section{ETHICS COMMITTEE APPROVAL}

The Butantan Institute was granted the license number 480548 by The Brazilian Institute of the Environment and Renewable Natural Resources (IBAMA) to raise snakes in captivity in order to use them in scientific research and display them to the public.

\section{CORRESPONDENCE TO}

Cristian Alexandro Gomes, Laboratório de Ecologia e Evolução, Instituto Butantan, Avenida Doutor Vital Brazil, 1500, São Paulo, SP, 05503900, Brasil. Phone: +55 113726 7222, ext. 2014. Email: biocristian@gmail.com.

\section{REFERENCES}

1. Christian KA, Tracy CR, Porter WP. Physiological and ecological consequences of sleeping-site selection by the Galapagos land iguana (Conolophus pallidus). Ecology. 1984;65(3):752-8.

2. Reinert HK, Zappalorti RT. Timber rattlesnakes (Crotalus horridus) of the Pine Barrens: their movement patterns and habitat preference. Copeia. 1988;1988(4):964-78.

3. Tozetti AM, Martins M. Habitat use by the South American rattlesnake (Crotalus durissus) in southeastern Brazil. J Nat Hist. 2008;42(19-20):143544.

4. Tozetti AM, Vettorazzo V, Martins M. Short-term movements of the South American rattlesnake (Crotalus durissus) in southeastern Brazil. Herp J. 2009;19:201-6.

5. Baxley D, Lipps GJ Jr, Qualls CP. Multiscale habitat selection by black pine snakes (Pituophis melanoleucus lodingi) in Southern Mississippi. Herpetologica. 2011;67(2):154-66.
6. Borges RC, Araújo AF. Seleção de habitat em duas espécies de jararaca (Bothrops moojeni Hoge e $B$. neuwiedi Wagler) (Serpentes, Viperidae). Rev Bras Biol. 1998;58(4):591-601.

7. Reinert HK. Habitat selection in snakes. In: Seigel RA, Collins JT, editors. Snakes: Ecology and Behavior. New York: McGraw-Hill, Inc; 1993. p. 201-40.

8. Ab'Saber JW. Os domínios morfoclimáticos na América do Sul. Primeira aproximação. Geomorfologia. 1977;52:1-23.

9. Vanzolini PE. Distributional patterns of South American lizards. In: Vanzolini PE, Heyer WR, editors. Proceedings of a Workshop on Neotropical Distribution Patterns. Rio de Janeiro: Academia Brasileira de Letras. 1988; p. 317-42

10. Sazima I. Um estudo de biologia comportamental de jararaca, Bothrops jararaca, com uso de marcas naturais. Mem Inst Butantan. 1988;50(3):83-90.

11. Sazima I. Natural history of jararaca pitviper, Bothrops jararaca in southeastern Brazil. In: Campbell JA, Brodie EDJr, editors. Biology of the Pitvipers. Texas: Selva Tyler. 1992; p. 199-216.

12. Campbell JA, Lamar W. The venomous reptiles of the Western Hemisphere. 2nd ed. New York: Cornell University Press. 2004.

13. Colli GR, Bastos RP, Araújo AFB. The character and dynamics of the cerrado herpetofauna. In: Oliveira PS, Marquis RJ, editors. The Cerrados of Brazil: Ecology and Natural History of a Neotropical Savanna. New York: Columbia University Press. 2002; p. 223-241.

14. Bastos EG, Araújo AF, Silva HR. Records of the rattlesnakes Crotalus durissus terrificus (Laurenti) (Serpentes, Viperidae) in the State of Rio de Janeiro, Brazil: a possible case of invasion facilitated by deforestation. Rev Bras Zool. 2005;22(3):812-5.

15. Dial BE. The thermal ecology of two sympatric, nocturnal Coleonyx (Lacertilia: Gekkonidae). Herpetologica. 1978;34(2):194-201.

16. Chandler CR, Tolson PJ. Habitat use by a boid snake (Epicrates monensis) and its anoline prey, Anolis cristatellus. J Herpetology. 1990;24(2):151-7.

17. Tozetti AM. Uso do ambiente, atividade e ecologia alimentar da cascavel (Crotalus durissus) em área de cerrado na região de Itirapina. [Thesis] São Paulo: Universidade de São Paulo; 2006.

18. Almeida-Santos SM, Salomão MG. Reproduction in neotropical pitvipers, with emphasis on species of the genus Bothrops. In: Schuett GW, Hoggren M, Douglas ME, Greene HW, editors. Biology of the Vipers. Carmel, Indiana: Eagle Moutain Publishing._2002; p. 445-62.

19. Marques OA, Eterovic A, Endo W. Seasonal activity of snakes in the Atlantic forest in southeastern Brazil. Amphibia Reptilia. 2001;20(1):103-11. 